\title{
EDA Gene Product
}

National Cancer Institute

\section{Source}

National Cancer Institute. EDA Gene Product. NCI Thesaurus. Code C159358.

A protein encoded by the EDA gene. 